\title{
The Psycholinguistic Portrait of the Traitor in Ukrainian Artistic Military Prose of the Second Half of the XX Century
}

\section{Психолінгвістичний портрет зрадника в українській художній воєнній прозі II половини XX століття}

\author{
Roman Dubrovskyi \\ Ph.D. in Philology
}

\author{
Роман Дубровський \\ кандидат філологічних наук
}

E-mail: dracroma2008@ukr.net

https://orcid.org/0000-0002-0002-4458-6504

\author{
Kremenets Regional \\ Humanitarian-Pedagogical Academy \\ named after Taras Shevchenko \\ $\triangle 1$, Litseina Str., Kremenets, \\ Ternopil Region, Ukraine, 47003
}

\author{
Кременеиька обласна \\ гуманітарно-педагогічна академія \\ ім. Тараса Шевченка \\ $\triangle$ вул. Ліцейна, 1, Кременець, \\ Тернопільська обл., Україна, 47003
}

Original manuscript received September 24, 2019

Revised manuscript accepted April 02, 2020

\begin{abstract}
The purpose of the study in the article is to identify the components of the psycholinguistic portrayal of the traitor in the Ukrainian artistic prose of the second half of the twentieth century.

Materials \& Methods. Elements of component analysis, method of classification, discourse analysis, content analysis, as well as lexico-semantic, associative methods were applied in the article and on the basis of these methods it has been provided the analysis of the images of the movie story "Ukraine in Fire» by O. Dovzhenko, the novel "House over a torso" by I. Kachurovsky, the novel "Whirlwind" by Yu. Mushketyk, the novel "The ground under the hooves" by V. Drozd).
\end{abstract}

Results. It is considered the place of traitor images in the structure of literary works. The emphasis is placed on the dynamics of their development within the artistic time

ISSN 2309-1797 (print) / 2415-3397 (online) 
space. The focus is also made on the psycholinguistic markers forming the hero's/ antihero's portrait in the creative work. Comparison of the methods of designing the image of the traitor at different levels of organization of the artistic text in all the analyzed works is carried out.

Conclusions. It has been found that the psycholinguistic content of the traitor character type is directly dependent on the author's self-esteem model. The external evaluation, as a rule, remains stable. The description of the traitor's psychological portrait in all cases shows the displacement of the axiological vector, the change of the poles of the opposition "one's own - another's». In general in the Ukrainian military prose of the second half of the twentieth century the linguistic-psychological portraits of the traitor-gadget, traitor-freak and traitor-punisher are most vividly presented. However, there are other models.

Key words: traitor, speech code, linguistic-psychological portrait, narrative, creative intention, lexeme, opposition "one's own - another's", communicative personality.

\section{Вступ}

Важливим смисловим стрижнем літератури про війну неодмінно є опозиція «свій - чужий». На думку В. Іванова та В. Топорова, вона актуалізується в наступних площинах: етнічній («вільний/полонений», «православний/католик» тощо), соціальній (різні соціальні групи одного етносу), міфологічно-релігійній («свій» співвідноситься 3 людським простором, «чужий» - iз демонічним) (Иванов \& Топоров, 1965: 156-159). Причому у випадку 3 воєнною прозою названа дихотомія не $\epsilon$ тотожною протиставленню «побратим - ворог». Адже поняття «чужий» передбачає позицію позазнаходження відносно певного окресленого «свого» аксіологічного простору. Відтак «чужим» $€$ той, хто не сповідує визначальних пріоритетів тієї чи іншої суспільної групи або суспільства загалом (до яких відносить себе автор).

Це стосується і літературних творів, присвячених зіткненню внутрішньої воєнної сили - народу, держави та сили зовнішньої, тобто інонародних нападників, завойовників, як от у мілітарній прозі про Другу світову. А. Савельєв зазначає, що

«ворожість у людському суспільстві пов'язується, пери за все, із чужорідністю (приналежністю до чужої зграї); чужинець джерело небезпеки, страху» (Савельєв, 2007: 62). 
The Psycholinguistic Portrait of the Traitor in Ukrainian Artistic...

Герої таких творів часто опиняються в ситуаціях, де сили нерівні i доводиться витискати максимум зі свого духу, винахідливості, зрештою, інстинкту самозбереження (в останньому випадку намагаючись не зашкодити успіху загальної справи).

У цій своєрідній когнітивній моделі поняттю «свій = побратим» протистоять аж два поняття - «чужий = ворог» та «свій (?) = ворог». В останньому випадку йдеться про зрадників, образи яких у воєнній художній прозі вибудовуються за різними психолого-поведінковими моделями - від співчутливо-дидактичної тональності, зображення «блукаючої» душі, маргінала до показу психічно неврівноваженого покидька 3 неконтрольованою жагою до вбивства. Прикметно, що «чужий», «зрадник» у тексті художнього твору завжди набуває певних психолінгвістичних маркерів через мовленнєвий код. Відтак зрадник на психолінгвістичному рівні поєднує риси «свого» i «чужого», причому їх співвідношення залежить від налаштованості автора на творення тієї чи іншої моделі особистості.

У психолінгвістиці, лінгвістиці, літературознавстві та історичній науці проблема візуалізації портрета зрадника залишається актуальною. Вона є предметом досліджень вітчизняних i зарубіжних учених (Агеєва, 1989; Humboldt, 1971; Иванов \& Топоров, 1965; Колошук, 2000; Михида, 2012; Откович, 2010; Overfield, 2018; Parikh, 2009; Савелюк, 2017; Соловей, 2014; Фізер, 1993; Чжиянь, 2016; Shell, 1998 та ін.).

Метою нашого дослідження $\epsilon$ виявлення складових психолінгвістичного портрета зрадника в українській художньому воєнному дискурсі II половини XX століття. Воно набуває актуальності у зв'язку зі значним розвитком мілітарної прози, присвяченої подіям АТО/ООС, автори якої орієнтуються на художні досягнення своїх попередників.

Дослідження формування художніх образів саме крізь призму психолінгвістичного вчення $є$ досить продуктивним, адже, як зазначає Л. Глоба,

«психолінгвістика вивчає тексти як иілісність, як «образ світу» автора тексту, який надалі сприймається конкретним читачем за певних об'єктивних та суб'єктивних умов» (Глоба, 2011: 133). 


\section{Методи та методики дослідження}

У дослідженні для вивчення різних рівнів представлення психолінгвістичного портрета зрадника в художніх текстах було обрано для аналізу найбільш показові твори української мілітарної прози другої половини XX століття - кіноповість «Україна в огні» О. Довженка, роман «Дім над кручею» I. Качуровського, роман «Віхола» Ю. Мушкетика, роман «Земля під копитами» В. Дрозда. Такий підбір текстів для аналізу допомагає зробити його різностороннім, адже йдеться не лише про різнопланові за змістовим та жанровим рівнями твори, але й про твори, написані авторами, котрі перебували по різні боки «залізної завіси».

Для реалізації мети дослідження було використано елементи компонентного аналізу (для розщеплення значення аналізованих слів на складові компоненти та подальшого їх зіставлення 3 іншими лексемами на основі семантичної спільності), методу класифікації (для групування мовленнєвих маркерів персонажівзрадників), дискурс-аналізу (для з'ясування способів мовленнєвого відображення автором свого розуміння суспільних реалій), контентаналізу (для пошуку в художніх текстах лексичних одиниць, які відображають мовленнєву характеристику різних психотипів зрадників, та представлення їх кількісних показників), а також лексико-семантичного, асоціативного методів (з метою з'ясування психосемантичного навантаження мовних одиниць).

Було досліджено психолінгвістичні маркери, які формують портрет героя у творі. На думку Ц. Чжияня,

«аналіз особливого лінгвопсихічного лексикону допомагає виявити лінгвопсихічний портрет персонажів, дозволяе реалізувати вивчення мовного портрета як особливої досліднищької практики» (Чжиянь, 2016: 192).

На важливості вивчення мови, а відтак i мовлення людини наголошує й В. Борботько, стверджуючи, що це

«надважливий фактор орієнтування людини у світі свойх иінностей» (Борботько, 2011: 58).

Характеризуючи психолінгвістичний портрет зрадника, вважаємо за необхідне здійснити аналіз окремих елементів структури 
The Psycholinguistic Portrait of the Traitor in Ukrainian Artistic...

мовної особистості, запропонованих Ю.М. Карауловим. Так, науковець у теоретико-гносеологічній моделі мовної особистості виділив 3 рівні: 1) вербально-семантичний, 2) когнітивний, 3) мотиваційно-прагматичний (Караулов, 1987). У контексті дослідження психолінгвістичного портрета найбільш важливим буде саме третій рівень, адже він пов'язаний із виявленням цілей, установок, мотивів та інтересів, які впливають на розвиток та поведінку особистості, іiі мовленнєву діяльність і відтак є ключовим для формування «ієрархії смислів і цінностей в ії мовній моделі світу» (Караулов, 1987: 38). А.В. Кириліна доповнила цю модель іще двома рівнями: емоційним та моторико-артикуляційним (Кирилина, 2002). Лінгвіст В.І. Карасик констатував, що мовна особистість у процесі спілкування - це комунікативна особистість, тобто

«узагальнений образ носія культурно-мовних $i$ комунікативнодіяльнісних цінностей, знань, установок і поведінкових реакцій» (Карасик, 2004: 22).

Науковець виділяє ціннісний, пізнавальний та поведінковий аспекти комунікативної особистості. Опираючись на наведені вище дослідження, здійснимо опору на лексичний рівень репрезентації психолінгвістичного портрета зрадника, зокрема, на лексеми на позначення емоційних станів зрадника, внутрішніх та зовнішніх мотивів, зовнішньої оцінки характеру.

\section{Результати та дискусії}

Автори по-різному вибудовують появу та еволюцію образів зрадників у творах, закладаючи конкретне ідейне спрямування та орієнтуючись на певне коло читачів, адже, як справедливо зауважує психолінгвіст Н. Чепелєва,

«найважливішою характеристикою тексту як моделі взаємодії автора і читача є його діалогічність» (Чепелева, 2008: 140).

Тож письменники показують поступове «визрівання» і розкриття на війні як ситуації особистісного вибору, раптову появу, самовиправдання, добровільне самозречення або ж вимушену приреченість, нігілізм зрадників тощо. Константою ж при поділі на героїв і відступників залишається формулювання 
«зрада Батьківщини» на противагу патріотизму, який, на думку психологів, полягає у

«наявності почуття любові до батьків, готовності приносити в жертву особисті інтереси, відповідній поведіниі, ототожненню себе зі своєю краӥною, ї̈ історією та народом» (Журавлев \& Юревич, 2016: 89).

Класичним прикладом психолінгвістичного портрета зрадника можна назвати Григорія Заброду 3 Довженкової «України в огні». Образ спроєктовано типово негативним, без жодних позитивних рис. Чоловік відверто ненавидить співвітчизників, їхні традиції. Письменник синтезує образ відступника через множинність варіантів його представлення у тексті. Таким чином створюється нова якість вербальної візуалізації відповідного образу. Так, В. Гумбольдт стверджував:

«Синтез створює щуось таке, щзо саме собою не існує в жодній складовій частині изілого» (Humboldt, 1971: 163).

О. Довженку вдалося створити таким способом сильний негативний тип, здатний закріпитися в пам'яті читача, адже при образотворенні важливою $є$ не лише творча інтенція письменника, але і здатність читача «вловити» ii або наповнити власним змістом. Iз цього приводу I. Фізер, аналізуючи психолінгвістичну теорію літератури О. Потебні, відзначає:

«Зміст художнього твору, так як він виникає в нашій свідомості, не є нерозбірливим додаванням семантичних компонентів твору, але зумисною кореляцією того, щзо ми вибираємо, затримуємо, трансформуємо $i$, звичайно, побільшусмо у нашому сприйнятті» (Фiзep, 1993: 42).

Цікаво, що О. Довженко, проєктуючи описані образи, використав своєрідний мовленнєвий код. Причому його подано на двох рівнях: 1) внутрішньому (самооцінка персонажа-зрадника та його мовленнєва самопрезентація, виражена в діалогах зі «своїми» та «чужими»; 2) зовнішньому (його оцінка як тими персонажами, що належать до концептосфери «Свій» iз позиції автора й відтак читача, так і тими, хто належить до категорії «Чужий» на етнопсихологічному підгрунті). Так, психолінгвістичний портрет Заброди репрезентується мовленнєвими зразками на позначення 
The Psycholinguistic Portrait of the Traitor in Ukrainian Artistic...

вислужування (клянусь честю, господин полковник, Ваше високоблагородіє) та ненависті (я ненавиджу радянську владу), самолюбства (жертва класової боротьби, велику книгу можна написати про мої страждання). Зовнішня його оцінка подана як погляд на «чужого» 3 обох ворогуючих сторін. Земляки сприймають його як чужого ментально (соціальна площина опозиції «свій чужий»), що виявляється у відповідній мовленнєвій оцінці: падлєц, курва, погана людина, падлюка, ворог мій, німецький пес, лакиза німецька, німецький запроданець тощо. Також у повісті є оцінна характеристика, передана словосполученням «нечиста сила», що характеризує т.з. міфологічно-релігійну площину опозиції «свій чужий». Три останні означення вибудувані на основі етнічної опозиції. «Чужі», до яких Заброда прилаштувався, сприймають його як недостойну людину, що виявляється в номінаціях сволоч, мерзотник та ін.

Тож у психолінгвістичному плані образ зрадника в межах опозиції «свій - чужий» вербалізується через ті ж лексичні одиниці, що й інші образи з ворогуючих таборів, проте зазнає зміщення їх вектор. Так, персонаж-зрадник асоціює себе зі «своїм» у таборі «чужих», відтак його етнос стає йому ментально чужим, що виражається відповідним мовленнєвим кодом. Проте у тексті важко знайти елементи «свого» мовленнєвого коду, які б стосувалися описаного зрадника.

I. Качуровський у романі «Дім над кручею» показує повернення молодого інтелігента - сина розкуркуленого і засудженого до розстрілу більшовиками Сергія Ремеза. Автор через головного персонажа подає власні аксіологічні орієнтири. Зрадниками у творі $є$ посібники радянської влади. Більшовики вдаються до звірства над власним народом. У романі $є$ багато моментів із описом як фізичного болю, так і болю суспільного, асоційованого з приходом антигуманної влади. Причому для опису фізичних та соціальних страждань вжито одні і ті ж лексеми (болить, ниє, нуртує, страждає, тамують, пече та ін.). Е. Бореллі, Д. Крепальді, К.А. Порро та К. Кацціарі відзначають, що така вербалізація болю є досить типовою:

«У різних мовах використовуються слова на позначення фізичного болю для опису досвіду болю соціального» (Borelli, Crepaldi, Porro \& Cacciari, 2018: 3). 
I. Качуровський описує, як більшовики вбили селянина, випатрали його, голову повісили на кілок, а кишками перетягнули стежку, лишивши безграмотну записку: «СДЕСЬ СОВЕЦКАЯ ВЛАСТЬ НЕМЦАМ СТАРОСТАМ И ПОЛИЦАЯМ В ХОД ВОСПРЕЩАЕЦА». Важливо, що в тексті твору великими літерами передано дослівний зміст напису (до речі, до такого психологічно-візуалізаційного прийому вдавався ще Микола Хвильовий!). Цей епізод транслює авторську позицію відносно радянської влади: це влада жорстоких неосвічених убивць.

Показово, що у творі використано саме транслітеровану лексему «совєтський» без ії перекладу («радянський»). Такий підхід дозволив авторові виділити ментальну віддаленість селян і носіїв комуністичних ідей. Однак усе вище сказане не свідчить про те, що в дихотомії «побратими - зрадники» просто поміняні місцями вектори. Тож поліцаї описуються майже 3 тим же зневажливим пафосом, як і в творах «канонізованих» епіків війни:

«Без знання німещької мови, без вищої освіти - у нас тут $i$ кур'єр з вищою освітою - нічого не вийде. Хібащз запропонуйте свої послуги міській поліиіі. Там, пробачте, усяку шпану збирають» (збережено граматику і стилістику тексту - Р.Д.) (Качуровський, 1966: 24).

Автори мілітарної художньої прози 3 різною глибиною досліджують проблему зрадництва. Одні своїм завданням вважають створення схематичного ескізу людини-відступника із набором стереотипних негативних рис. Така поверхневість вказує на факультативну роль цих образів, яка полягає в увиразненні образів героїв, борців, народних месників тощо. Інші показують зрадництво як раптове викриття істинного обличчя людини, яке відбулося завдяки війні як екстремальній обставині або окремому іiі епізоду, ситуації тощо. Треті промальовують у найдрібніших деталях образ зрадника, представляючи мотивацію усіх його дій (внутрішню самого героя або зовнішню - авторську) та простежуючи еволюцію його морального падіння. На поліфонічності образу зрадника в художній прозі про війну наголошує й В. Агеєва:

«Звернення до страмної долі відступника, зрадника Вітчизни було пов'язане з різними ідейно-естетичними завданнями, а відтак бачимо і різне художнс вирімення иієї теми, і неоднакові 
The Psycholinguistic Portrait of the Traitor in Ukrainian Artistic...

морально-духовні акценти, розставлені письменниками» (Агеєва, 1989: 163).

Для прикладу, у романі «Віхола» Ю. Мушкетика проблема зрадництва представлена на рівні абстрактних узагальнень, у яких прискіпливий читач може виразно відчути присутність авторського голосу в творі. Вдаючись до філософського відступу як художнього прийому налагодження імпліцитного діалогу з читачем, письменник подає такі думки щодо проблеми зрадництва і зрадників:

«Війна понаплутувала, навихрила, відгадувати людей було до ката важко. Директор передового радгоспу раптом виявився начальником поліції, а запеклий одноосібник, записаний $у$ підкуркульники за те, щуо довго не хотів вступати до колгоспу, відмовився від посади сільського старости, і його привселюдно відимагали шомполами» (Мушкетик, 1983: 207).

Водночас подальший розвиток сюжетної лінії дає практичне підтвердження цих слів. Так, гостинний господар Коробочка через власний страх та малодушність виказує німцям утікачів (головних героїв). Автор не тільки передає в діалозі розмову героїв, коментує їхні вчинки, але й детально описує їх стан, кожну емоцію. I якраз через останнє вказує на зрадника серед «своїх»:

«Неначе гостра, розжарена скалка, зблиснула думка про Коробочку, прийшов запізнілий розгад його розмови з сусідом, дряпонула кігтями злість і згинула, поглинута іншою думкою щุo робити?» (Мушкетик, 1983: 294).

Образ зрадника подається фрагментарно, малими розрізненими штрихами в окремих фрагментах тексту. На читача покладається обов'язок зрозуміти авторський задум, зібрати в одне ціле елементи розкиданої мозаїки, представленої окремими лексемами в різних частинах наративу. Це стосується й образу «чужого серед своїх» Віталика Соболя. Його вбивають після того, як він приводить ворогів на місце закопаного районного архіву.

Одним із центральних персонажів роману «Земля під копитами» В. Дрозда $є$ староста Степан Савич Конюш, він же Шуляк, котрий пов'язує своє заможне майбутнє 3 воєнними успіхами загарбників. Автор показує його в різних ситуаціях, через різні вчинки, пориви, думки. Фактично, його влада та падіння стають ядром усього сюжету. Тут читач зустрічається 3 
детально промальованим образом не ситуативного, а ідеологічного, виваженого, внутрішньо сформованого зрадника. Він стає символом усього внутрішнього зла, від якого війна, як це не парадоксально, очистила нашу землю.

Допомагає забезпеченню цього ефекту також створення топосу «родового гнізда» антигероя. Це велетенський будинок, у якому, за мріями Шуляка, і пустить коріння його династія:

«Шуляк підійшов до вікна, поторгав раму: як влита у дубові бруси. Не на день будувалося, не на два - на віки <..> У иибках, затінених знадвору ніччю $і$ віконницями, відбилось вилицювате Степанове обличчя. Шуляк різко одвернувся од вікна» (Дрозд, 1989: 138-139).

Автор робить акцент на сприйнятті обличчя негативного героязрадника. Б. Рі, досліджуючи сприйняття та мовленнєве вираження концепту «обличчя» у дисертаційному дослідженні «Філософія обличчя та література i культура XX століття», наголошує на тому, що

«дуже мало частин людського тіла наділені культурними асочіачіями так, як обличчя» (Rhie, 2005: 20).

Краса та надійність будови у фрагменті протиставлені зовнішній потворності як відображенню внутрішньої дисгармонії персонажазрадника. Він намагається досягнути психологічної безпеки, створюючи зовнішнє безпечне середовище свого існування, проте фізично не може досягнути своєї мети, оскільки психологічна безпека залежить, у першу чергу, від обраної траєкторії руху особистості, а відтак, i ii вчинків. У цьому контексті Н. Савелюк наголошує:

«Психологічна безпека асоціюється не стільки з мірою адаптованості, в тому числі, сочіальної, до вимог середовища, з належними - безпечними умовами даного середовища, скільки з конструктивною діяльністю самого суб'єкта, котрий здійснює свідомий вибір того чи іншого иляху свого розвитку» (Савелюк, 2017: 310).

Цікаво, що автор подає десятки ситуацій, в яких проявляє себе й еволюціонує (чи то - на рівні аналізу особистості - деградує) образ зрадника. Однак вони не $є$ однотипними. Щоразу нова 
The Psycholinguistic Portrait of the Traitor in Ukrainian Artistic...

подія відкриває чергову грань моральної деградації героя. Часто ці іпостасі виявляються й завдяки позасюжетним композиційним елементам. До них, зокрема, належать внутрішні діалоги. Наведемо як приклад частину такої самосповіді:

«Жінки - тільки поле для засіву, а коли орача цікавило, щуо думає поле?» (Дрозд, 1989: 155).

Шуляк показаний людиною, котра увібрала в себе, наскільки розум та різниця в менталітеті дозволили це зробити, чужі ідеологічні та психологічні риси і по-своєму інтерпретує та впроваджує їх у власному житті. Тож він думає тільки про власне продовження, вбачаючи в дитині лише свій генетичний код, а жінка для нього лише функція і засіб для задоволення:

«Він володіє ї̈ молодим тілом, і тільки. Втім, $і$ тіло ї̈ з першої їхньої ночі було покірне, податливе, але безмовне. Він помщався за ту безмовність, місив його, як тісто. Ліза вставала з ліжка в синиях, але наступної ночі знову була ніби підстелюшка, ніби за гроші» (Дрозд, 1989: 140).

Слова та вирази підстелюшка, місив тіло та інші $\epsilon$ частиною авторського гетеродієгетичного наративу. Письменник третьоособовою нарацією подає, у тому числі, й самооцінку персонажа, покликану заповнити прогалини в його рецепції читачем. Наведемо приклад такого авторського «втручання»:

«Взимку буде два роки, як Ліза спить із ним в одному ліжку, а досі викає. Спериу Степан дратувався, тепер звик. Як-не-як, двадиять років різниці. Знову ж - його поважне становище. Для всіх - пан староста, а вона щзо - не з тої череди? Якщзо власна жінка не боятиметься, хто ж буде боятися?» (Дрозд, 989: 140).

Образотворчими лексемами в наведеному випадку слугують слова 3 асоціосфер «Страх», «Худоба», психологічно протиставлені асоціосфері «Повага». Хоча частково йдеться про ситуації емоційної напруги, в яких, як відзначає О. Соловей,

«мовець обирає слова із чітким позитивним або негативним значенням, тобто переважає крайня полярність в оцінках» (Соловей, 2014: 283).

Тож при представленні мовного портрета зрадника відбувається зіставлення «Я» (поважне становищуе, пан староста) та «Вони» 
(череда, боятиметься). Риторичні питання, подані як внутрішній монолог героя під строгим контролем авторського голосу в тексті, покликані надати цілісності обраній наративній стратегії.

Прикметно, що антигерой-зрадник не має у творі дзеркального рівносильного та відповідно вербально представленого ідеологічного антипода. Це пов'язано, по-перше, $з$ тим, що автор формує в читачів думку про те, що таким антиподом $є$ весь народ, від якого цей віроломник відрікся. А по-друге, в романі усе ж показано образ, який так чи інакше є одним із кількох центрів зображення. Це Галя Поночівна. Вона не є лідером антифашистського опору, а просто жінкою, котра намагається фізично вижити, при цьому зберігаючи найкращі моральні риси українського народу. Як виявляється згодом, вона здатна пройти немало смертельних випробувань, як згодом і Степан Конюш.

Результативним у контексті вивчення психології зрадника/ незрадника є аналіз способів виживання. Галі Поночівні це вдається завдяки інстинкту самозбереження, який поширюється на оберігання власних дітей, без жодної шкоди іншим людям, які також мають жагу до життя. У цьому контексті С. Михида зазначає:

«Будь-яка активність людини (мислення, сприймання, пам'ять i увага) визначається інстинктами. Вплив останніх на поведінку може бути як безпосереднім, так і опосередкованим, замаскованим. Люди поводять себе так чи так, бо їх спонукає підсвідома напруга - їх дії послуговують меті зменшення иієё напруги» (Михида, 2012: 172).

Фактично, у романі представлені дві моделі поведінки людини в умовах окупації: співпраця з тимчасовими переможцями, незважаючи на принесення у жертву своїх співвітчизників та спроба виживання без відмови від власних принципів, аксіологічних орієнтирів i морального кодексу народу. Причому в першому випадку, коли йдеться про формування місцевих владних інституцій, організацію нового суспільного устрою, це спочатку пов'язується 3 духовним розворотом на 360 градусів, а потім зводиться до банальних первинних інстинктів, серед яких найперший - інстинкт виживання. У другому випадку навпаки - спочатку йдеться про фізичне виживання, успішність якого дозволяє людині не забувати про власну суспільну сутність, а відтак - про обов'язки перед тими, поряд із ким доводилося жити до війни та під час війни. Тобто 
The Psycholinguistic Portrait of the Traitor in Ukrainian Artistic...

мовиться про нову можливість поступового руху пірамідою потреб, описаною А. Маслоу, - від задоволення фізіологічних потреб аж до самоактуалізації (Маслоу, 2009).

Спираючись на проаналізовані тексти, можемо запропонувати трикомпонентну модель особистості зрадника на війні (див. рис. 1):

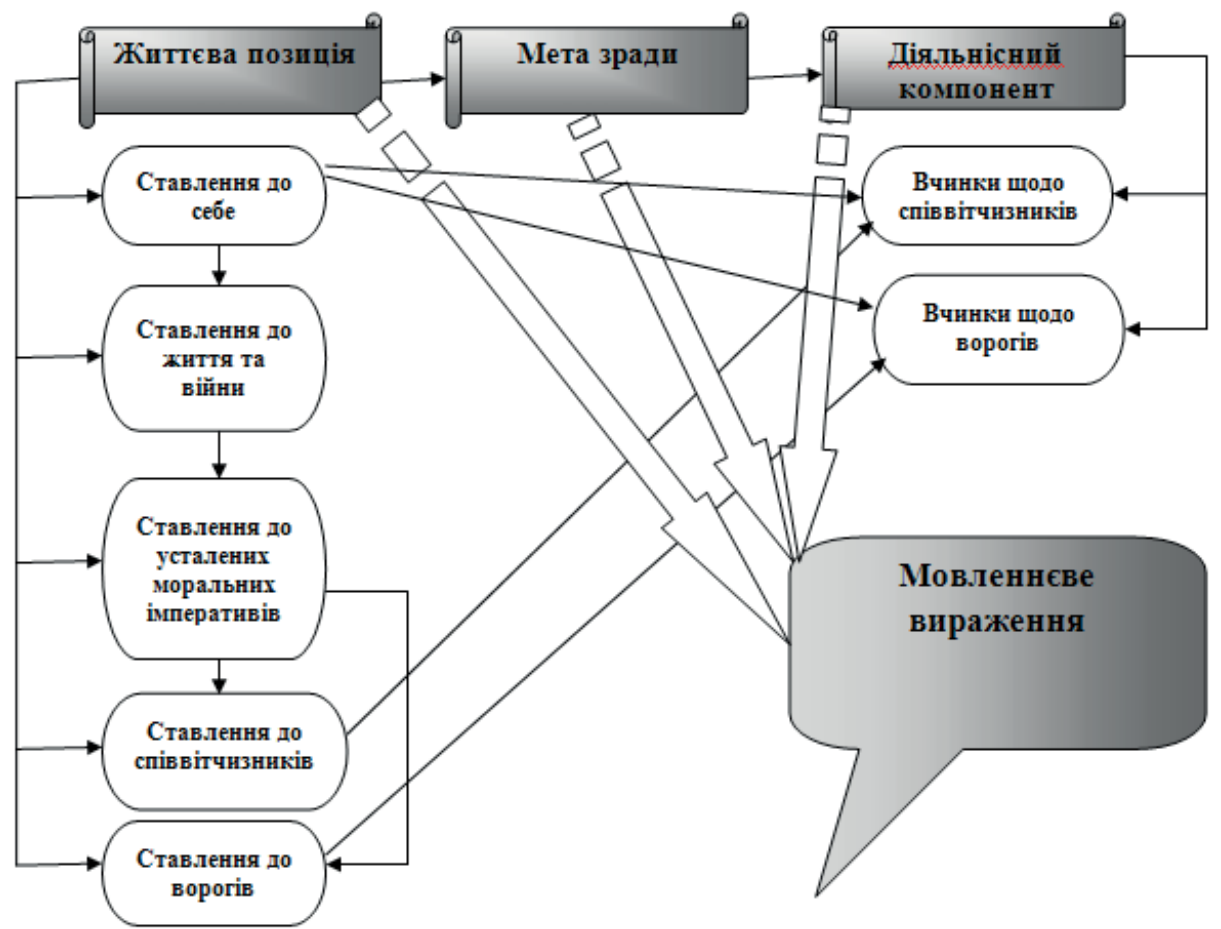

Рис. 1. Модель особистості зрадника на війні

Звичайно, наведена модель $\epsilon$ досить умовною та не відображає вичерпного переліку особистісних рис, мотивів, етапів формування людини-зрадника. Однак вона дозволяє простежити динаміку становлення портрета зрадника від моменту формування стійкої життєвої позиції, що проявляється у ставленні до себе, життя та війни як ситуації виклику, до сформованих у «своєму» соціумі (чи мікросоціумі) етичних норм, а відтак - і у ставленні до співвітчизників (концептосфера «Свій») та ворогів (концептосфера «Чужий»), до часу реалізації цієї життєвої позиції через конкретні вчинки, направлені на співвітчизників та на ворогів. Ці два полюси опосередковує мета зради (вижити, отримати владу тощо), яка, 
як і причина, завжди є присутньою. Усі компоненти цієї моделі так чи інакше вербалізуються в аналізованих творах, набуваючи відповідного мовленнєвого вираження.

На основі розглянутих психолінгвістичних портретів у текстах, які складали джерельну базу нашого дослідження, можемо виокремити певні типи образів зрадників із відповідними мовленнєвими маркерами. Тож найбільш впізнаваними $є$ такі психотипи: 1) пристосуванець; 2) слабодух; 3) каратель. Перший тип (пристосуванець) задовольняється базовими елементами піраміди Маслоу - фізіологічними потребами та потребами власної безпеки. Другий тип (слабодух) показаний зрадником за обставинами через психологічну та фізіологічну нездатність обійтися без названих вище потреб, страх власної загибелі чи болю. Третій тип (каратель) - показується людиною з патологічною жагою до помсти своїм співвітчизникам за завдані ними збитки. В умовах війни він отримує шанс піднятися навіть до рівня самоствердження та самовираження, щоправда, лише через зраду. Мовленнєву характеристику описаних типів подаємо у таблиці 1.

При всій строкатості підходів до зображення війни та зрадників в умовах війни автори подають мовленнєві портрети, які так чи інакше відповідають певним типам людей-маргіналів. Психолінгвістичний портрет зрадника в українській воєнній прозі другої половини XX століття має чимало варіантів та модифікацій, що залежить від майстерності, творчої волі письменника, ідеї самого художнього твору. Найчастіше він є носієм психологічного типу, який досягається як особливим типом представлення самооцінки від самозвеличення (Шуляк у «Землі під копитами» В. Дрозда) i самовдоволення (Заброда в «Україні в огні» О. Довженка) до самовиправдання (Соболь і Коробочка у «Віхолі» Ю. Мушкетика) і навіть самозречення (Чобіт у «Домі над кручею» I. Качуровського), так і зовнішньої оцінки через авторські відступи та мовлення інших персонажів.

Аналіз висловлювань персонажів-зрадників показав, що в основному вони належать до кількох тематичних груп: «Страх», «Безвихідь», «Самовиправдання», «Жорстокість». У таблиці 2 подано кількісну характеристику лексичних одиниць кожної із названих груп у розрізі аналізованих творів. Вважаємо такий підхід найбільш виправданим, оскільки кожен із наведених вище типів 


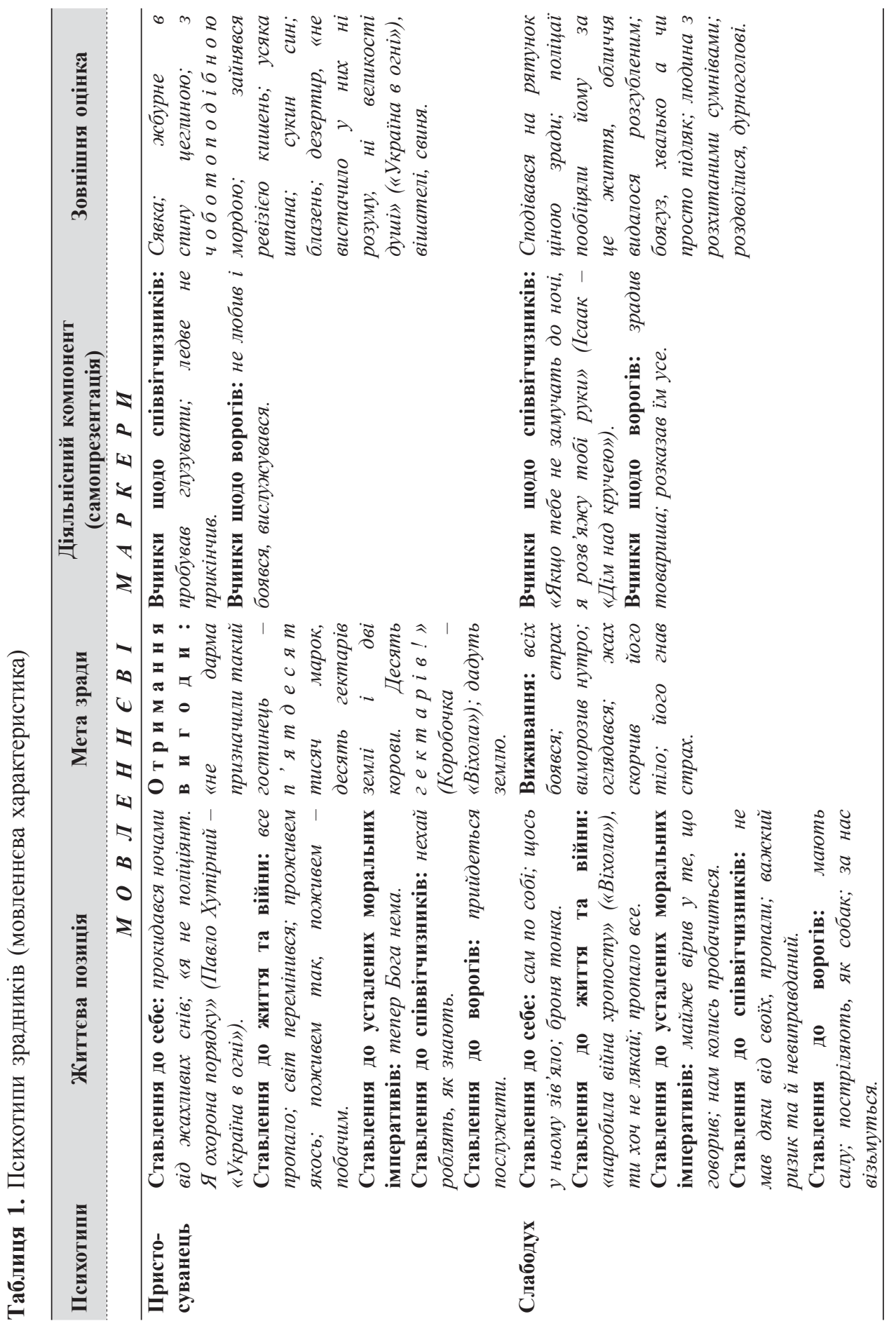




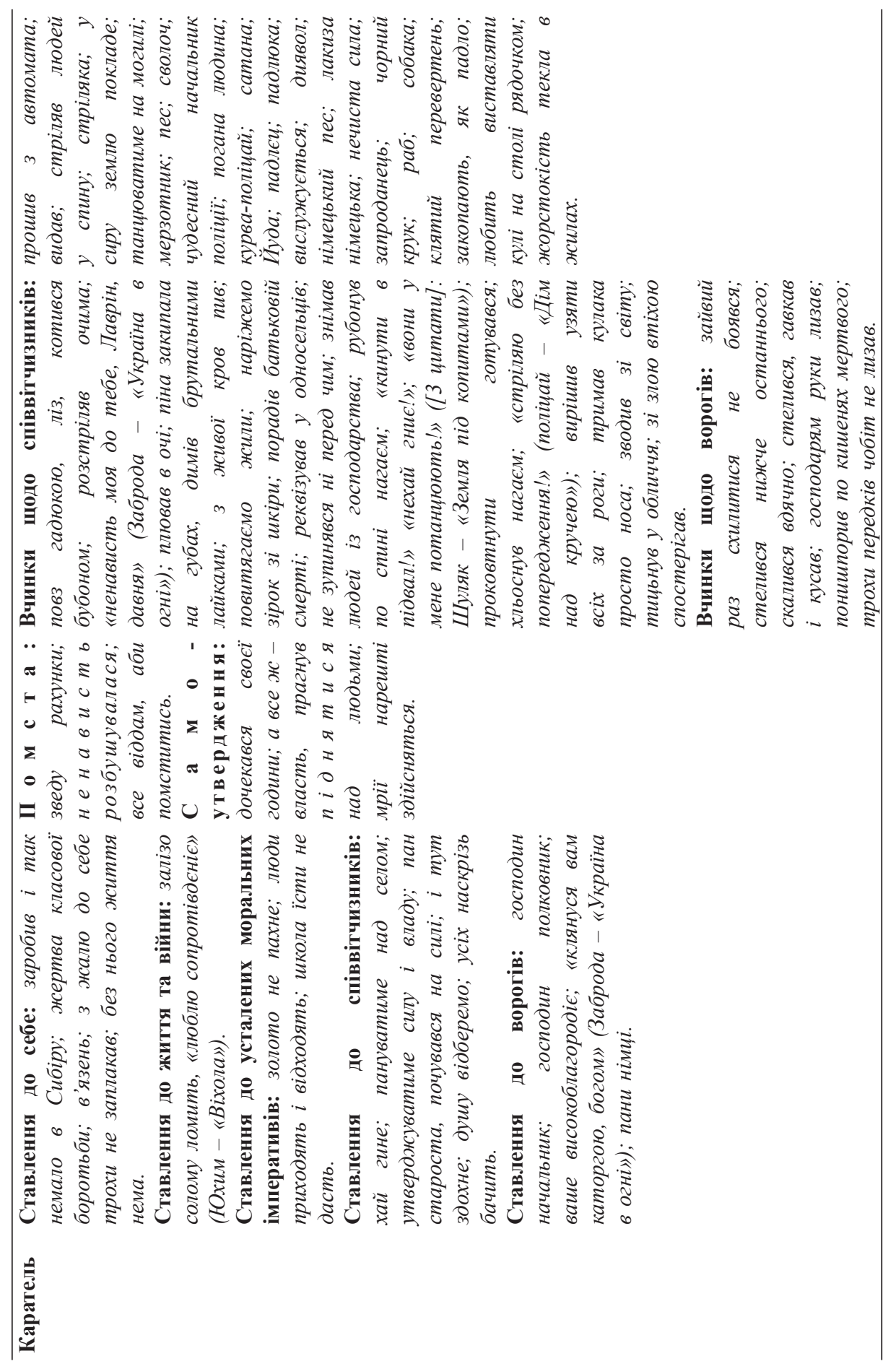


The Psycholinguistic Portrait of the Traitor in Ukrainian Artistic...

зрадників більшою чи меншою мірою наділений рисами інших типів, а приналежність персонажа то конкретного типу визначалася за переважаючими мовленнєвими маркерами.

Таблиця 2. Тематика висловлювань персонажів-зрадників (кількісна характеристика)

\begin{tabular}{lcccc}
\hline \multicolumn{1}{c}{ Твір } & \multicolumn{4}{c}{ Тематична група } \\
& Страх & Безвихідь & Самовиправдання & Жорстокість \\
\hline «Україна в огні» & $15(16,5 \%)$ & $12(13,2 \%)$ & $21(23,0 \%)$ & $43(47,3 \%)$ \\
«Дім над кручею» & $8(22,2 \%)$ & $7(19,4 \%)$ & $4(11,1 \%)$ & $17(47,3 \%)$ \\
«Віхола» & $16(34,8 \%)$ & $8(17,4 \%)$ & $5(10,9 \%)$ & $17(36,9 \%)$ \\
«Земля під копитами» & $21(9,3 \%)$ & $33(14,6 \%)$ & $19(8,4 \%)$ & $153(67,7 \%)$ \\
\hline
\end{tabular}

Наявність майже однакової кількості висловлювань, які належать до різних тематичних груп, у межах одного твору пояснюється зображенням у ньому кількох персонажів-зрадників, які загалом належать до різних виділених нами типів (наприклад, пристосуванця та карателя або слабодуха і пристосуванця). Усе ж за наведеною кількісною характеристикою мовлення можна простежити домінуючі психотипи зрадників у межах кожного аналізованого твору. Так, для карателів найбільш характерними $є$ висловлювання із тематичної групи «Жорстокість», для слабодухів «Страх» та «Безвихідь», для пристосуванців - «Самовиправдання» та «Безвихідь».

Слід відзначити, що комплексний психолінгвістичний портрет зрадника формується як на рівні окремих лексем та фразем, так i на рівні цілих описових речень, мовленнєвих ситуацій тощо. Тож усвідомлення його цілісності, структури можливе тільки при знайомстві 3 повним текстом художнього твору, на основі розуміння підтексту, авторської позиції, іноді - сатири чи іронії. Також письменники при наділенні образів зрадників певними типовими рисами, які простежуються через лінгвістичні маркери, намагалися надати їм індивідуальних рис, які також знайшли словесне вираження в діалогах та авторських ремарках (наприклад, Юхим любив «виставляти кулі на столі рядочком», дивитися на «сопротівлєніє» і т. д.). 


\section{Висновки}

Можемо узагальнити, що в українській воєнній прозі найяскравіше представлені психолінгвістичні портрети зрадникапристосувания; зрадника-слабодуха та зрадника-карателя. Проте існують також інші моделі.

Психолінгвістичний образ пристосувания, як правило, формується через його зовнішню номінацію або характеристику (подається через мовлення інших персонажів чи оцінку всезнаючого наратора) i значно меншою мірою - через самопрезентацію в діалогах чи внутрішніх діалогах. В аналізованих текстах співвідношення речень із зовнішньою оцінкою та речень із показом позиції персонажа становить 7:1. Серед лексем, які презентують мовлення зрадника-пристосуванця, найбільш уживаними $є$ слова на позначення ставлення до світу, його динаміки під час війни (все пропало, світ перемінився) та самовиправдання.

Образи зрадників-слабодухів $\epsilon$ найменш численними у художній «воєнній літературі» (в аналізованих текстах -2 із 12). На відміну від зрадників-пристосуванців, їхній психолінгвістичний портрет формується в основному завдяки самопрезентації, тобто через мовленнєві маркери, що характеризують життєву позицію, причини та мету зради персонажів (як правило, бажання зберегти життя, вербалізоване лексемами та фраземами 3 концептосфери «Страх»). Якщо пристосуванець намагається знайти на війні хоча б мінімальну вигоду для себе, то слабодух боїться іiі та прагне врятуватися навіть ціною зради (сподівався на рятунок иүіною зради; людина з розхитаними сумнівами).

Найбільш повно представленим через мовленнєве вираження $€$ портрет карателя. Його зрада є осмисленою. Він має чітку систему орієнтирів. Ворог залишається для нього чужим, притому каратель вислуговує перед ним (господин начальник, господин полковник, ваше високоблагородіє), а співвітчизники знаходяться нижче нього, про що свідчать мовленнєві маркери пануватиме над селом, утверджуватиме силу $i$ владу, душу відберемо та інші. Метою його зради є помста і самоутвердження. Притому зовнішня характеристика цього типу зрадників $\epsilon$ також досить широкою. Вона реалізується завдяки лексемам зі зниженою конотацією (аж до 
The Psycholinguistic Portrait of the Traitor in Ukrainian Artistic...

обсценної лексики). Цікавим є показ ненависті через використання конфесіоналізмів на позначення зрадника чи представника злої трансцендентної сили (Йуда, диявол, перевертень, сатана). Оскільки, як правило, йдеться про антигероя, то його життєва позиція також достатньо вербалізована.

3'ясовано, що психолінгвістичне наповнення типу образу персонажа-зрадника перебуває у прямій залежності від наданої йому автором самооцінної моделі. При цьому зовнішня оцінка, як правило, залишається стабільною. Доведено, що при формуванні психолінгвістичного портрета зрадника в усіх випадках показано зміщення аксіологічного вектора, зміну полюсів опозиції «свій - чужий». Іноді автори ставлять образ відступника в центр художнього зображення, простежуючи його еволюцію в мирний час, час окупації та час визволення, що знаходить вияв, у першу чергу, в різному підборі елементів мовленнєвого коду (через авторські відступи, внутрішні монологи самого зрадника, діалоги, опис вчинків антигероя та їх імпліцитну чи формально виражену оцінку автором, портрет, інтер'єр, екстер'єр тощо).

Назагал проблема формування лінгвопсихологічного портрета зрадника все ще залишається малодослідженою у вітчизняній науці, що створює обшир для майбутніх студій. Наведені моделі не вичерпують усього художнього потенціалу для проектування типів відступників. АТО/ООС, які стали випробуванням для українського народу та поставили багатьох людей у ситуацію вибору, породила цілий пласт цікавої художньої прози, в якій образ зрадника також представлений повною мірою. Тож порушена нами проблема матиме перспективи для подальшого наукового дослідження.

\section{Література}

Агеєва, В.П. (1989). Пам'ять подвигу (українська воєнна проза 60-80-х років). Київ: Наукова думка.

Борботько, В.Г. (2011). Принциипь формирования дискурса: от психолингвистики $\kappa$ психосинергетике (4-е изд.). Москва: Либроком.

Глоба, Л. (2011). Психолінгвістичні аспекти сприйняття і розуміння художнього тексту. Психологія особистості, 1 (2), 132-137.

Довженко, О. (н. д.). Україна в огні. Режим доступу: http:/www.ukrlib.com.ua/ books/printitzip.php?tid $=876$

Дрозд, В.Г. (1989). Вибрані твори (Т. 1-2), (Т. 2, с. 552). Київ: Радянський письменник. 
Журавлев, А.Л., \& Юревич, А.В. (2016). Патриотизм как объект изучения психологической науки. Психологический журнал, 37 (3), 88-98.

Иванов, В.В., \& Топоров, В.Н. (1965). Славянские языковые моделирующие семиотические системь. Москва: Наука.

Карасик, В.И. (2004). Языковый круг: личность, концепты, дискурс. Москва.

Караулов, Ю.Н. (1987). Русский язык и языковая личность (7-е изд.). Москва : Издательство ЛКИ.

Качуровський, I. (1966). Дім над кручею. Мюнхен: Дніпрова хвиля.

Кирилина, А.В. (2002). Проблемы гендерного подхода в изучении межкультурной коммуникации. Гендер как интрига познания (с. 17). Москва.

Колошук, Н.Г. (2000). Воєнна проза В. Астаф'єва в контексті «армійської» та табірної літератури. Науковий вісник Волинського державного університету ім. Лесі Українки. Філологічні науки, 6, 325-335.

Маслоу, А. (2009). Мотивация и личность (3-е изд.). Санкт-Петербург: Питер.

Михида, С.П. (2012). Психопоетика украӥнського модерну: проблема реконструкиії особистості письменника. (Монографія). Кіровоград: Поліграф - Терція.

Мушкетик, Ю.М. (1983). Віхола. Київ: Молодь.

Откович, К. (2010). Ілюзія свободи: образ жінки від традиціоналізму до модернізму. (Монографія). Київ : КАРБОН.

Савелюк, Н.М. (2017). Психологія розуміння релігійного дискурсу. (Монографія). Київ: КНТ.

Савельев, А.Н. (2007). Образ врага. Расология и политическая антропология. Москва: Белые альвы.

Соловей, О.А. (2014). Психолінгвістичні особливості усного мовлення особистості в ситуації емоційної напруги. Психологічні перспективи, 23, 276-287.

Фізер, I. (1993). Психолінгвістична теорія літератури Олександра Потебні: метакритичне дослідження. Київ: Academia.

Чепелева, Н. (2008). Текст как объект психологического исследования. Психолінгвістика, 1, 138-151.

Чжиянь, Ц. (2016). Модели речевого портрета и лингвопсихический портрет драматических персонажей в пьесе А.П. Чехова «Дядя Ваня». Историческая u сочиально-образовательная мысль, $8(5 / 2), \quad$ 190-194. https://doi. org/10.17748/2075-9908-2016-8-5/2-190-194

Borelli, E., Crepaldi, D., Porro, C.A., \& Cacciari, C. (2018). The psycholinguistic and affective structure of words conveying pain. PLOS ONE, 13 (6), 1-29. https://doi. org/10.1371/journal.pone.0199658

Humboldt, W. (1971). Linguistic variability \& intellectual development. Coral Gables, Florida: University of Miami Press.

Overfield, C. (2018). All Quiet on the West German Front: Changes in East German Political Agitation in Western Germany, 1945-1955. Penn History Review, 25 (1).

Parikh, C. (2009). An Ethics of Betrayal: The Politics of Otherness in Emergent U.S. Literatures and Culture. New York: Fordham University Press. https://doi. org/10.2307/j.ctt13x08bm

Rhie, Bernard J. (2005). The Philosophy of the Face and 20th Century Literature and Art. Doctor's of Philosophy thesis. Philadelphia.

Shell, O.C. (1998). Cleansing the nation: Italian art, consumerism, and World War I. Doctor's of Philosophy thesis. Philadelphia. 
The Psycholinguistic Portrait of the Traitor in Ukrainian Artistic...

\section{References}

Ageyeva, V.P. (1989). Pamyat podvigu (ukrayinska voyenna proza 60-80-h roki [Memory of the feat (Ukrainian military prose of the 60's and 80's)]. Kyiv: Naukova dumka [in Ukrainian].

Borbotko, V.G. (2011). Princzipy formirovaniya diskursa: ot psikholingvistiki $k$ psikhosinergetike [The principles of discourse formation: from psycholinguistics to psychosynergetics] (4th ed.). Moscow: Librokom [in Russian].

Hloba, L. (2011). Psykholinhvistychni aspekty spryiniattia i rozuminnia khudozhnoho tekstu [Psycholinguistic aspects of the perception and understanding of artistic text]. Psykholohiia osobystosti - Psychological features, 1 (2), 132-137 [in Ukrainian].

Dovzhenko, O. (n. d.). Ukrayina v ogni [Ukraine on fire]. Retrieved from http://www. ukrlib.com.ua/books/printitzip.php?tid=876 [in Ukrainian].

Drozd, V.G. (1989). Vibrani tvori [Selected Works]. (Vols. 1-2), (Vol. 2, p. 552). Kyiv: Radyanskij pismennik [in Ukrainian].

Zhuravlev, A.L., \& Yurevych, A.V. (2016). Patriotizm kak obyekt uzucheniya psihologicheskoj nauki [Patriotism as an object of study of psychological science]. Psihologicheskij zhurnal - Philosophical Journal, 37 (3), 88-98 [in Russian].

Ivanov, V.V., \& Toporov, V.N. (1965). Slavyanskie yazykovye modeliruyushie semioticheskie sistemy [Slavic language modeling semiotic systems]. Moscow: Nauka [in Russian].

Karasyk, V.I. (2004). Yazyikovyiy krug: lichnost, kontseptyi, diskurs [Language Circle: Personality, Concepts, Discourse]. Moscow [in Russian].

Karaulov, Yu.N. (1987). Russkij yazyk i yazykovaya lichnost [Russian language and linguistic personality] (7th ed.). Moscow: Izdatelstvo LKI [in Russian].

Kachurovskij, I. (1966). Dim nad krucheyu [House over the cliff]. Myunhen: Dniprova hvilya [in Ukrainian].

Kirilina, A.V. (2002). Problemy gendernogo podhoda v izuchenii mezhkulturnoj kommunikacii [Problems of gender approach in the study of intercultural communication]. Gender kak intriga poznaniya - Gender as the intrigue of knowledge (p. 17). Moscow [in Russian].

Koloshuk, N.H. (2000). Voienna proza V. Astafieva v konteksti «armiiskoi» ta tabirnoi literatury [V. Astaf'evs military prose in the context of «army» and camp literature]. Naukovyi visnyk Volynskoho derzhavnoho universytetu im. Lesi Ukrainky - Scientific Bulletin of Volyn State University named after Lesya Ukrainka, 6, 325-335 [in Ukrainian].

Maslou, A. (2009). Motivacziya i lichnost [Motivation and personality] (3rd ed.). Sankt-Peterburg: Piter [in Russian].

Myhyda, S.P. (2012). Psyhopoetyka ukrayinskoho modernu: problema rekonstrukciyi osobystosti pysmennyka [Psycho-poetics of Ukrainian modernity: the problem of reconstruction of the writer's personality]. Kirovograd: Poligraf - Terciya [in Ukrainian].

Mushketik, Yu.M. (1983). Vihola [Milestone]. Kyiv: Molod [in Ukrainian].

Otkovych, K. (2010). Iliuziia svobody: obraz zhinky vid tradytsionalizmu do modernizmu [The illusion of freedom: the image of women from traditionalism to modernism]. Kyiv: KARBON [in Ukrainian]. 
Savelyuk, N.M. (2017). Psihologiya rozuminnya religijnogo diskursu [The illusion of freedom: the image of women from traditionalism to modernism]. Kyiv: KNT [in Ukrainian].

Savelev, A.N. (2007). Obraz vraga. Rasologiya $i$ politicheskaya antropologiya [The image of the enemy. Racology and political anthropology]. Moscow: Belye alvy [in Russian].

Solovei, O.A. (2014). Psykholinhvistychni osoblyvosti usnoho movlennia osobystosti $\mathrm{V}$ sytuatsii emotsiinoi napruhy [Psychological linguistic peculiarities of the internal level of specialty in the situation of emotional tension]. Psykholohichni perspektyvy - Psychological perspective, 23, 276-287 [in Ukrainian].

Fizer, I. (1993). Psiholingvistichna teoriya literaturi Oleksandra Potebni: Metakritichne doslidzhennya [Psycholinguistic Theory of Literature by Alexander Potebny: A Metacritical Study]. Kyiv: Academia [in Ukrainian].

Chepeleva, N. (2008). Tekst kak objekt psikhologicheskogo issledovaniya [The text as an object of psychological research]. Psikholingvistika - Psycholinguistics, 1, 138-151 [in Russian].

Chzhiyan, C. (2016). Modeli rechevogo portreta i lingvopsihicheskij portret dramaticheskih personazhej v pese A.P. Chehova «Dyadya Vanya» [Models of speech portraiture and linguistic psychic portrait of dramatic characters in AP Chekhov's play Uncle Vanya]. Istoricheskaya $i$ socialno-obrazovatelnaya mysl - Historical and Socio-Educational Thought, 8 (5/2), 190-194. https://doi. org/10.17748/2075-9908-2016-8-5/2-190-194 [in Russian].

Borelli, E., Crepaldi, D., Porro, C.A., \& Cacciari, C. (2018). The psycholinguistic and affective structure of words conveying pain. PLOS ONE, 13 (6), 1-29. https://doi. org/10.1371/journal.pone.0199658

Humboldt, W. (1971). Linguistic variability \& intellectual development. Coral Gables, Florida: University of Miami Press.

Overfield, C. (2018). All Quiet on the West German Front: Changes in East German Political Agitation in Western Germany, 1945-1955. Penn History Review, 25 (1).

Parikh, C. (2009). An Ethics of Betrayal: The Politics of Otherness in Emergent U.S. Literatures and Culture. New York: Fordham University Press. https://doi. org/10.2307/j.ctt13x08bm

Rhie, Bernard J. (2005). The Philosophy of the Face and 20th Century Literature and Art. Doctor's of Philosophy thesis. Philadelphia.

Shell, O.C. (1998). Cleansing the nation: Italian art, consumerism, and World War I. Doctor's of Philosophy thesis. Philadelphia.

\begin{abstract}
АНОТАЦІЯ
Метою дослідження $\epsilon$ виявлення складових психолінгвістичного портрета зрадника в українській художній воєнній прозі II половини ХХ століття.

Методи дослідження. У статті було застосовано елементи компонентного аналізу, методу класифікації, дискурс-аналізу, контент-аналізу, а також лексико-семантичного, асоціативного методів та на їх основі здійснено аналіз образів кіноповісті "Україна в огні» О. Довженка, роману "Дім над кручею» І. Качуровського, роману «Віхола» Ю. Мушкетика, роману «Земля під копитами» В. Дрозда.
\end{abstract}


The Psycholinguistic Portrait of the Traitor in Ukrainian Artistic...

Результати. Розглянуто місце образів зрадників у структурі літературних творів. Зроблено акцент на динаміці їх розвитку в межах художнього часопростору. Також увагу зосереджено на психолінгвістичних маркерах, що формують портрет героя/антигероя героя у творі. Здійснено зіставлення засобів проектування образу зрадника на різних рівнях організації художнього тексту в усіх аналізованих творах.

Висновки. 3'ясовано, що психолінгвістичне наповнення типу образу персонажазрадника перебуває у прямій залежності від наданої йому автором самооцінної моделі. При цьому зовнішня оцінка, як правило, залишається стабільною. При описі портрета зрадника в усіх випадках показано зміщення аксіологічного вектора, зміну полюсів опозиції "свій - чужий». Загалом в українській воєнній прозі другої половини XX століття найяскравіше представлені психолінгвістичні портрети зрадника-пристосувания, зрадника-слабодуха та зрадника-карателя. Проте існують також інші моделі.

Ключові слова: зрадник, мовленнєвий код, психолінгвістичний портрет, наратив, творча інтенція, лексема, опозиція "свій - чужий», комунікативна особистість.

\section{Дубровский Роман. Психолингвистический портрет предателя в украинской художественной военной прозе второй половины XX века}

\section{АННОТАЦИЯ}

Целью исследования является выявление составляющих психолингвистического портрета предателя в украинской художественной военной прозе второй половины XX века.

Методы исследования. В статье были использованы элементы компонентного анализа, метода классификации, дискурс-анализа, контент-анализа, а также лексико-семантического, ассоциативного методов и на их основе осуществлен анализ образов киноповести "Украина в огне» А. Довженко, романа "Дом над обрывом» И. Качуровского, романа "Метель» Ю. Мушкетика, романа "Земля под копытами» В. Дрозда.

Результаты. Рассмотрено место образов предателей в структуре литературных произведений. Сделан акцент на динамике их развития в пределах художественного пространства-времени. Также внимание сосредоточено на психолингвистических маркерах, которые формируют портрет героя/антигероя героя в произведении. Осуществлено сопоставление средств проектирования образа предателя на разных уровнях организации художественного текста во всех анализируемых произведениях.

Выводы. Выяснено, что психолингвистическое наполнение типа образа персонажа-предателя находится в прямой зависимости от предоставленной ему автором самооценочной модели. При этом внешняя оценка, как правило, остается стабильной. При описании портрета предателя во всех случаях показано смещение аксиологического вектора, изменение полюсов оппозиции 
Психолінгвістичний портрет зрадника в украӥнській художній...

«свой - чужой». В целом в украинской военной прозе второй половины XX века ярко представлены психолингвистических портреты предателяприспособленца, предателя-слабодуха и предателя-карателя. Однако существуют и другие модели.

Ключевые слова: предатель, речевой код, психолингвистический портрет, нарратив, творческая интенция, лексема, оппозиция "свой - чужой», коммуникативная личность. 